\title{
Factors Affecting The Use Of WTO Fiscal Protection Instruments
}

\author{
Göksel Karaş** $^{* *}$
}

RESEARCH

ARTICLE

\begin{tabular}{|c|c|}
\hline ARTIC & \\
\hline Submitted : 04.04.2021 & \multirow{8}{*}{$\begin{array}{l}\text { Many countries, especially developed countries, have been trying to } \\
\text { liberalize international trade for many years. Although it is intended to } \\
\text { liberalize international trade, countries do not hesitate to use protection } \\
\text { policy instruments. Within the means of protectionism, fiscal protection } \\
\text { instruments are the most popular instruments, consisting of anti- } \\
\text { dumping, countervailing duty and safeguards, following the invisible } \\
\text { obstacles. This article examines the macroeconomic factors affecting the } \\
\text { use of fiscal protection instruments for country groups and each country } \\
\text { through the negative binomial regression analysis between the years } \\
\text { 1995-2016. As a result of the analysis, only the real exchange rate affected } \\
\text { the use of fiscal protection instruments in high-income countries, while } \\
\text { the growth rate, real exchange rate, and unemployment rate affect the } \\
\text { low and middle-income countries. This shows that high-income countries } \\
\text { do not use fiscal protection instruments fairly and the low and middle- } \\
\text { income countries act with completing their economic development and } \\
\text { macroeconomic concerns. }\end{array}$} \\
\hline Revised :02.06.2021 & \\
\hline Accepted : 09.06.2021 & \\
\hline Available : 30.06 .2021 & \\
\hline $\begin{array}{l}\text { iThenticate similarity } \\
\text { score: } 15 \%\end{array}$ & \\
\hline $\begin{array}{l}\text { JEL classification: } \\
\text { C35, F13, P45 }\end{array}$ & \\
\hline Keywords: & \\
\hline $\begin{array}{l}\text { Fiscal Protection } \\
\text { Instruments, Negative } \\
\text { Binomial Regression, } \\
\text { WTO }\end{array}$ & \\
\hline
\end{tabular}

Cite this article as: Karaş, G. (2021). "Factors Affecting The Use Of WTO Fiscal Protection Instruments", International Journal of Public Finance, 6(1), 97-114.

\section{Introduction}

Due to the developments in the world, the necessity of the states to exist in the economy is evolving. The international trade system is also affected. In times of economic expansion, the free trade system is adopted with a minimal state view, and

\footnotetext{
* This study is composed of the PhD thesis prepared by the Bursa Uludag University Social Sciences Institute, Department of Public Finance.

** Res. Assist. PhD., Kutahya Dumlupinar University, Department of International Trade and Finance, ORCID: 0000-0003-4091-1258, goksel.karas@dpu.edu.tr
} 
protectionism is adopted with the view of the interventionist state in times of economic recession. In line with the developments in time, the market understanding of the states also changes. From the beginning of the 16th century to the end of the 18th century, the prevailing thought in the world is mercantilism. According to mercantilism, countries' sources of wealth are the precious metals that they hold. While the input of precious metals into the country is allowed through export, the exit of precious metals from the country through imports is prevented. This period is the period in which protectionist policies are implemented in international trade with government interventions. With the Industrial Revolution, liberal thoughts gained weight and the idea of intervention in the market was replaced by the thought of determining the functioning of the market according to supply and demand conditions. Since the thought of market economy was dominant in this period, the obstacles in front of international trade were tried to be liberalized by removing them. In 1929, with the Great Depression, the assumptions defended by liberal policies began to be questioned. Keynesian thought, which believes that the way out of the crisis is through state interventions, has become the dominant paradigm. Again, in this period, state interventions were seen intensely and protectionist policies gained weight throughout the world. The change in thought about state-market relations and the conditions brought by the Second World War increased the protectionist policy practices at the national level. In the process until the Second World War, countries acted individually against the balance of payments deficit and unemployment problems they faced instead of cooperating with each other. However, in this process in which mutual tariffs were increased, the volume of foreign trade shrank significantly. In response to increasing protectionist policies, efforts to liberalize world trade gained momentum. As a result of these efforts, the Bretton Woods negotiations began.

These developments are shaped by the states, which are the hegemonic power of the period. The United States of America (USA), the hegemonic power of the period, advocated the free trade system to be dominated by removing barriers to international trade with the negotiations of Bretton Woods, which began in 1944. For this purpose, the World Bank (WB) and the International Monetary Fund (IMF) were established, and the General Agreement on Tariffs and Trade (GATT) was signed. After this period, the international trade system has been developing in the free trade base, although it is mainly applied in the protectionist policies in times of economic crises. Because the liberalization of international trade has theoretically increased the welfare of all countries of the world. In this context, World Trade Organization (WTO) was established in 1995. Today, the WTO aims to liberalize international trade between 164 member states. Therefore, WTO advocates removing barriers to the liberalization of international trade, excluding the exceptional cases. These exceptions are infant industry, national security, strategic trade policy, Generalized Preferences System and unfair competition. 
Karaş, G. (2021). "Factors Affecting The Use Of WTO Fiscal Protection Instruments", International Journal of Public Finance, 6(1), 97-114.

Today, unfair competition increases conflicts between countries. These conflicts also affect international trade relations (Gbakou et al., 2007: 2). Anti-dumping duty against anti-dumping practices and countervailing duty against subsidies are applied. These measures, known as temporary trade barriers (TBT) in the literature, can also be called fiscal protection measures regarding the effects on countries' public finances (Engin, 1992: 82-93).

This study aims to investigate the economic factors affecting the use of fiscal protection instruments allowed under the WTO, based on the country groups and each country-specific. The study will contribute to the literature as it examines the factors affecting all fiscal protection instruments and analyzes the country basis on current data according to the studies in the literature. A model has been created that the number of financial protection instruments used in the world is the dependent variable and the growth rate, the share of imports in GDP, the ratio of exports to imports, the real exchange rate and the unemployment rate are independent variables. The hypotheses created within this scope are tested by negative binomial regression (NBR) analysis.

\section{Literature Review}

When the literature is examined, no study has been found that takes into account the sum of fiscal protection instruments within the scope of WTO. However, in the literature, there are studies on the determinants of anti-dumping and countervailing duty which are fiscal protection instruments. The first empirical study was done by Finger et al. (1982). In the study, it is stated that anti-dumping practices in the USA result from political pressures by using the logit model. Feinberg (1989) found that the exchange rate was effective in anti-dumping investigations by using a Tobit model, whereas Feinberg (2004) concluded that the exchange rate was positive and the real GDP was negative in initiating anti-dumping investigations by NBR analysis. Leidy (1997) found that the unemployment rate and exchange rate had positive effects as expected and the use of capacity had a negative effect on anti-dumping and countervailing measures in the USA. Knetter \& Prusa (2003) conducted a study on four major anti-dumping users and had similar results with Feinberg (2004). Aggarwal (2004), which uses different variables with the NBR analysis method, concluded that the growth in foreign trade balance and imports were effective in anti-dumping investigations, and developed countries used anti-dumping practices, especially for protectionist purposes. According to Irwin (2005), the exchange rate and the share of imports in GDP were effective in anti-dumping investigations. Blonigen (2005) also found that the exchange rate was effective in both anti-dumping and countervailing measures similar to the literature. Mah \& Kim (2006) found that there is a relationship 
between real GDP growth and anti-dumping investigations as a result of the cointegration test in Korea, which is different from the literature, and that anti-dumping taxes made the economic activities slow. Hallworth \& Piracha (2006) obtained similar results with Knetter \& Prusa (2003) and Feinberg (2004), but, unlike the literature, it had a direct relationship between the other country's GDP and anti-dumping investigations. Gbakou et al. (2006), in the study for the USA and the EU, the exchange rate for both countries has a similar positive effect, whereas the fluctuations in economic activity only have a significant negative effect in the USA. Also, the concentration of imports increases anti-dumping investigations for the US, while the opposite effect for the EU. Bown (2008) found similar results with studies in the literature. Macro variables and intra-industry variables are effective in the antidumping investigation. Moore \& Zanardi (2009), investigating whether anti-dumping investigations are being used by countries for escape clauses, has concluded that the safety valve argument is not supported and that anti-dumping measures serve to hamper trade liberalization. Zhou \& Cuyvers (2009), Zeng (2011), Choi \& Kim (2014), Bagchi et al. (2015) and Li (2018), similarly macroeconomic variables were effective in anti-dumping investigations, Egger \& Nelson (2011) has concluded that the antidumping investigations affected the world trade volume and world welfare. In the literature, it is found that anti-dumping investigations are carried out by retaliation between countries (Moore \& Zanardi, 2001: 601-619). Özer \& Erkal (2016) studied the relationship between macroeconomic variables and antidumping investigations for Turkey. They have concluded that the import growth rate has positive, Turkey's GDP growth rate has negative and growth rates of 10 countries that have been mostly indicted anti-dumping prosecutions by Turkey has positive effect on Turkey's antidumping implementations. Wang (2016) concluded that when foreign countries' macroeconomic circumstance was worse, they would tend to initiate more antidumping investigations against China. Desai \& Feinberg (2019) investigated the effect of increasing tariffs on antidumping investigations during the Trump era. The authors reject a hypothesis of substitution away from antidumping in the Trump era of general protectionism. Selen (2020) stated that the country groups use TTB for the macroeconomic necessities and protective policies.

As can be seen in the literature review, this study will support the literature in two aspects. First, it contributes to the empirical literature on the relationship between growth rate, the share of imports in GDP, the ratio of exports to imports, the rate of the real exchange rate and the rate of unemployment and trade protectionism. Secondly, this contribution to the literature includes evaluations regarding both country groups and countries. 


\section{Econometric Method}

\subsection{Data Set}

The research was designed in two stages. Firstly, 17 countries that mostly use fiscal protection instruments were grouped and analyzed by taking into consideration the country grouping by the World Bank. In the second stage, analysis based on each country was made. Table 1 shows the country groups.

Table 1: Country Groups

\begin{tabular}{cl}
\hline High-Income Countries & Low and Middle-Income Countries \\
\hline Australia & Argentina \\
European Union & Brazil \\
Japan & South Africa \\
Canada & China \\
Korea & Turkey \\
USA & Mexico \\
Chile & Russia \\
& Guatemala \\
& India \\
& Indonesia \\
\hline
\end{tabular}

Source: World Bank, (12.12.2018)

In the study, which was formed to determine the factors affecting the use of fiscal protection instruments, the use of fiscal protection instruments (sum of antidumping measures, countervailing measures and safeguards) between the years 1995 - 2016 are considered as a dependent variable, and macroeconomic variables such as the economic growth, the share of imports in GDP, the ratio of exports to imports, the rate of the real exchange rate and unemployment are considered as independent variables The aim of this study is to investigate the factors that affect the use of protectionism policy instruments in the period of the World Trade Organization. For this reason, the first 17 countries using these instruments and the years 1995 (WTO foundation year) - 2016 (date of study) were taken into consideration as a sample according to the WTO database. As a matter of fact, when the studies in the literature are examined, it is considered that the sample time interval (22 years) is sufficient (Knetter \& Prusa, 2003; Aggarwal, 2004; Feinberg, 2005; Jallab et al., 2009; Zhou \& Cuyvers, 2009; Choi \& Kim, 2014; Bagchi et al., 2015). In Table 2, the status and source of variables used in the analysis have been seen. 
Karaş, G. (2021). "Factors Affecting The Use Of WTO Fiscal Protection Instruments", International Journal of Public Finance, 6(1), 97-114.

Table 2: Variables of Analysis

\begin{tabular}{llcl}
\hline Abbreviation & \multicolumn{1}{c}{ Variable Name } & Source & Variable Status \\
\hline FPI & Fiscal Protection Instruments & WTO & Dependent \\
GRW & Growth Rate & WB & Independent \\
IGDP & The share of imports in GDP (\%) & WB & Independent \\
EXIM & Import Ratio of Exports (\%) & WB & Independent \\
REXC & Real Exchange Rate & WB & Independent \\
UNEMP & Unemployment & WB & Independent \\
\hline
\end{tabular}

In determining the variables used in the study, the literature was examined, and the variables commonly used in the literature were used. Table 3 shows the reference of variables.

Table 3: Reference of Variables

\begin{tabular}{ll}
\hline Variable & Reference \\
\hline \multirow{3}{*}{ GRW } & Knetter \& Prusa (2003), Feinberg (2004), Blonigen (2005), \\
& Bown (2008), Zhou \& Cuyvers (2009), Zeng (2011), Choi \& \\
& Kim (2014), Feinberg \& Reynolds (2017) \\
IGDP & Irwin (2005), Zeng (2011) \\
EXIM & Bagchi et al. (2015) \\
& Feinberg (1989), Knetter \& Prusa (2003), Feinberg (2004), \\
& Irwin (2005), Blonigen (2005), Bown (2008), Zhou \& \\
REXC & Cuyvers (2009), Jallab et al. (2009), Zeng (2011), Liu \& Deng \\
& (2016) \\
& Irwin (2005), Blonigen (2005), Bown (2008), Zhou \& \\
UNEMP & Cuyvers (2009), Zeng (2011), Choi \& Kim (2014) \\
\hline
\end{tabular}

\subsection{Hypotheses}

The basic hypotheses that are formed to determine the factors affecting the use of fiscal protection instruments are as follows:

$\mathrm{H}_{1}$ : There is a negative relationship between growth and fiscal protection instruments.

Decreases in domestic production of countries mean that economic activities are slowing down. In this case, countries implement policies to boost economic activities by increasing production. For this reason, the input of imported products to the country is reduced and the demand is directed to domestic products. Knetter \& Prusa (2003: 7) stated that the decrease in GDP growth caused firms to decrease their profitability and 
Karaş, G. (2021). "Factors Affecting The Use Of WTO Fiscal Protection Instruments", International Journal of Public Finance, 6(1), 97-114.

countries were more likely to resort to protectionist policy instruments. A negative relationship is expected between these variables.

$\mathrm{H}_{2}$ : There is a positive relationship between the share of imports in GDP and fiscal protection instruments.

Excessive increases in countries' imports lead to an increase in the share of imports in GDP. This is because domestic production decreases due to excessive imports and causes negative effects on the domestic industry. In the event of an increase in the share of imports in GDP, countries seek the protection of domestic industry by means of protection policy instruments and aim to increase GDP by increasing domestic production. Irwin (2005: 10) stated that the share of imports in GDP increased rapidly in the USA and this situation led to an increase in protectionist policies. A positive relationship is expected between these variables.

$\mathrm{H}_{3}$ : There is a negative relationship between the ratio of exports to import and fiscal protection instruments.

The positive developments experienced in this ratio, which is also known as the ratio of exports to imports, are desirable for countries. While the increase in EXIM leads to a decrease in the application rates of the countries to protection instruments, in the opposite case, in the case of a decrease in EXIM, it increases the application rates of countries to protection policy instruments (Bagchi et al., 2015: 284). A negative relationship is expected between these variables.

$\mathrm{H}_{4}$ : There is a negative relationship between the real exchange rate and fiscal protection instruments.

When the studies in the literature are examined (Feinberg, 1989: 706; Knetter \& Prusa, 2003: 7), it is observed that a significant appreciation in the national currency increases the protection demands of the domestic industry, which is at risk of increasing as a result of the cheapening of imports. Therefore, a negative relationship is expected between these variables.

$\mathrm{H}_{5}$ : There is a positive relationship between unemployment and fiscal protection instruments.

Imports, which have become extremely cheap due to the cheapening of imports and other reasons, cause the demand to shift to foreign products and the domestic industry suffers from this situation. If no measures are taken, the domestic industry opts to cost minimization by laying off workers in order to respond to increasing competition. This leads to an increase in the unemployment rate. Countries resort to 
protectionist policy instruments to halt the increase in unemployment caused by excessive imports (Irwin, 2005: 10-11; Blonigen, 2005: 415; Zeng, 2011: 203). Therefore, a positive relationship is expected between these variables.

For empirical analysis, it is important to decide on the lag structure of the variables. Normally, the implementing countries analyze the pricing behavior of foreign firms in the year before opening the case. This is called the investigation time. The damage resulting from the protection is analyzed for at least three years. This period is usually called the investigation period. It is used to establish a relatively long period, especially causality. Because, in order to initiate an investigation, there must firstly be a causal link between the import and the damage suffered by the domestic industry. However, if this link is established, an investigation can be initiated (Başkol, 2010: 110). The margin calculations of the losses incurred during the investigation are based on the available data during this period of one year before applying the protectionist instruments (Aggarwal, 2004: 1048).

\subsection{Model}

The econometric model for determining the factors affecting the use of fiscal protection instruments in the world between 1995 and 2016 is as follows:

$$
\begin{aligned}
F P I= & \beta_{0}+\beta_{1} G R W_{i, t-1}+\beta_{2} I G D P_{i, t-1}+\beta_{3} E X I M_{i, t-1}+\beta_{4} R E X C_{i, t-1} \\
& +\beta_{5} U N E M P_{i, t-1}+\varepsilon_{i t}
\end{aligned}
$$

The summary table of the expected effects of the independent variables on the dependent variable is given in Table 4.

Table 4: Expected Impact of Variables

\begin{tabular}{clc}
\hline Abbreviation & Variable Definition & Expected Impact \\
\hline GRW & Growth Rate & Negative \\
IGDP & The share of imports in GDP (\%) & Positive \\
EXIM & Import Ratio of Exports (\%) & Negative \\
REXC & Real Exchange Rate & Negative \\
UNEMP & Unemployment & Positive \\
\hline
\end{tabular}

NBR analysis method was used in the study. Because linear regression analysis is based on the assumption that the dependent variable is a continuous random variable. In cases where the dependent variable is not continuous, estimation by linear regression analysis may cause erroneous results. A variable obtained by counting cannot have a normal distribution (because there are continuous variables that can 
take all values). Instead, the distribution of data obtained by counting is Poisson distribution (Wooldridge, 2002: 605). Poisson regression analysis is used to analyze the data with Poisson distribution. However, in the case of overdispersion or underdispersion, the variance of the observed values is larger or smaller than the mean. In this case, an NBR model is used which is a generalized Poisson model (Aggarwal, 2004: 1049).

\section{Empirical Findings}

\subsection{Empirical Specification And Results}

In the analysis, descriptive statistical information related to variables were given firstly by country groups. The descriptive statistics of the country groups used in the analysis are given in Table 5.

Table 5: Descriptive Statistics by Country Groups

\begin{tabular}{llccccc}
\hline & Variable & Obs. & Mean & St.Dev. & Min. & Max. \\
\hline & FPI & 154 & 8.45 & 10.46 & 0 & 51 \\
& GRW & 154 & 2.83 & 2.42 & -5.47 & 11.31 \\
High-Income & IGDP & 154 & 22.41 & 11.32 & 6.73 & 57.49 \\
Country & EXIM & 154 & 100.95 & 14.22 & 64.48 & 149.45 \\
& REXC & 154 & 99.62 & 16.86 & 66.61 & 165.88 \\
& UNEMP & 154 & 6.44 & 2.31 & 2.05 & 11.31 \\
\hline \multirow{5}{*}{ Low and Middle- } & FPI & 220 & 8.72 & 10.81 & 0 & 66 \\
Income Country & IGDP & 220 & 18.08 & 9.07 & 4.23 & 41.35 \\
& EXIM & 220 & 102.73 & 23.70 & 59.52 & 212.28 \\
& REXC & 220 & 95.98 & 23.03 & 46.88 & 189.45 \\
& UNEMP & 220 & 7.94 & 6.13 & 1.3 & 27.14 \\
\hline
\end{tabular}

There are 154 observations from seven high-income countries, and 220 observations from ten low and middle-income countries. High-income countries at a mean (8.45) resorted to protection policy instruments at almost the same rate as low and middle-income countries (8.72). Low and middle-income countries had a higher growth rate compared to high-income countries. Low and middle-income countries (18.08\%) have a relatively low share of imports in GDP compared to high-income countries $(22.41 \%)$. Looking at the ratio of exports to imports, low and middle-income countries (102.73\%) are relatively higher than in high-income countries (100.95\%). 


\subsection{Results of Country Groups}

It was mentioned above that the use of Poisson regression analysis would give more significant results when the dependent variable was obtained by counting numbers. However, Poisson regression analysis does not give any significant results in cases where the dependent variable is overdispersed. The most important symptom of overdispersion or underdispersion can be obtained by comparing the mean and variance of the data that constitutes the dependent variable. In this case, the use of NBR analysis, which is a special case of Poisson regression analysis, is more accurate. The mean and variance of the dependent variable were compared in the study to determine which regression method would be appropriate.

Firstly, to make a comparison between high-income countries and low and middle-income countries, mean and variance are calculated and shown in Table 6.

Table 6: Mean and Variance by Country Groups

\begin{tabular}{lcc}
\hline Country Group & Mean & Variance \\
\hline High-Income Countries & 8.448 & 109.347 \\
Low and Middle-Income Countries & 8.718 & 116.824 \\
\hline
\end{tabular}

The mean consisting of high-income countries is 8.45 , and the variance is 109.35, the mean of the group consisting of low and middle-income countries is 8.72, and the variance is 116.82 . So, the variance of the dependent variable of the two countries is significantly greater than their mean. Therefore, it will be more accurate to use NBR analysis in the analysis of country groups. Secondly, one can see from Table 7 that more than $20 \%$ of the total observations of high-income countries and low and middle-income countries have zero values.

Table 7: Frequency and Percentages of FPI by Country Group

\begin{tabular}{|c|c|c|c|c|}
\hline \multirow{2}{*}{ Number of FPI } & \multicolumn{2}{|c|}{ High-Income Countries } & \multicolumn{2}{|c|}{ Low and Middle-Income Countries } \\
\hline & Frequency & Percentage & Frequency & Percentage \\
\hline 0 & 34 & 22.08 & 52 & 23.64 \\
\hline 1 & 13 & 8.44 & 17 & 7.73 \\
\hline 2 & 12 & 7.78 & 10 & 4.55 \\
\hline 3 & 9 & 5.84 & 9 & 4.09 \\
\hline 4 & 7 & 4.55 & 9 & 4.09 \\
\hline 5 & 8 & 5.19 & 14 & 6.36 \\
\hline 6 & 9 & 5.84 & 7 & 3.18 \\
\hline 7 & 3 & 1.95 & 11 & 5 \\
\hline 8 & 4 & 2.6 & 11 & 5 \\
\hline 9 & 3 & 1.95 & 13 & 5.91 \\
\hline 10 and + & 52 & 33.78 & 67 & 30.45 \\
\hline
\end{tabular}


Figure 1 and Figure 2 also suggests that our dependent variable (FPI) is positively skewed ${ }^{1}$.

Figure 1: Low and Middle Income Countries

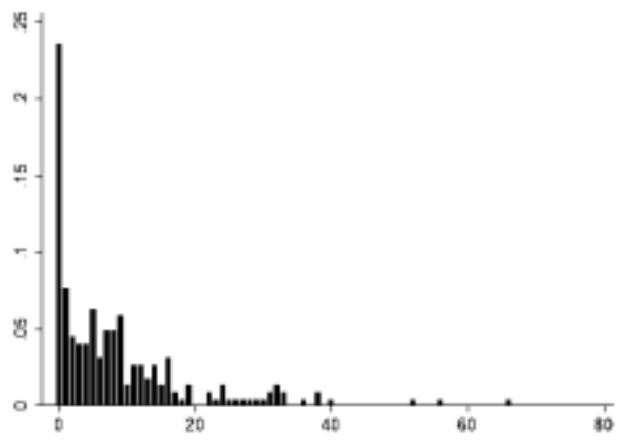

Figure 2 High Income Countries

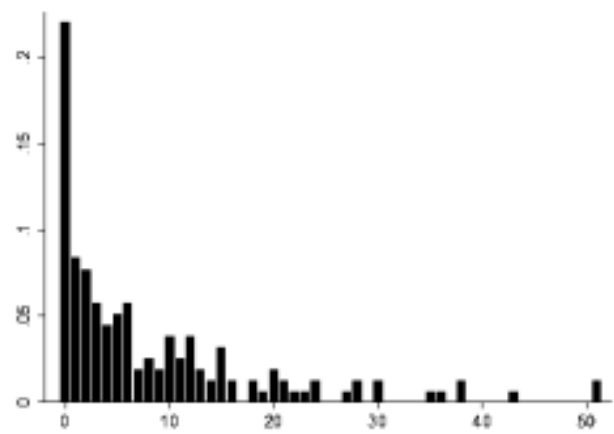

This suggests that negative binomial regression analysis should be used rather than Poisson analysis. Subsequently, it was started to determine whether the negative binomial regression analysis used was predicted by fixed effects or random effects. At this stage, the Hausman (1978) test was used. According to the Hausman test result, the test statistic is 14.94 and the probability chi2 value is 0.0106 . Thus, the fixed effects model should be used since the prob>chi2 is significant at $5 \%$. The results of the estimation model with fixed effects model are given in Table 8.

Table 8: Results of Panel Negative Binomial Regression Analysis Based on Country Groups

\begin{tabular}{lcc}
\hline & High-Income Countries & Low and Middle-Income Countries \\
\hline \multirow{2}{*}{ GRW } & 1.041 & 0.952 \\
& $(1.17)$ & $(-3.15)^{\mathrm{i}}$ \\
IGDP & 0.987 & 1.014 \\
& $(-1.52)$ & $(1.58)$ \\
EXIM & 0.999 & 1.004 \\
& $(-0.18)$ & $(1.05)$ \\
REXC & 1.016 & 1.011 \\
& $(2.93)^{\mathrm{i}}$ & $(3.50)^{\mathrm{i}}$ \\
UNEMP & 1.039 & 0.965 \\
& $(0.71)$ & $(-2.48)^{\mathrm{v}}$ \\
C & 0.556 & 0.521 \\
& $(-0.58)$ & $(-0.97)$ \\
\hline
\end{tabular}

\footnotetext{
${ }^{1}$ The dependent variable is found to have skewness and kurtosis to be 1.86 and 6.61 for high-income country and 2.12 and 8.69 for low and middle-income country, respectively.
} 
Karaş, G. (2021). "Factors Affecting The Use Of WTO Fiscal Protection Instruments", International Journal of Public Finance, 6(1), 97-114.

\begin{tabular}{lcc}
\hline Loglikelihood & -352.05 & -530.66 \\
Wald chi2 & 15.64 & 31.64 \\
Obs. & 147 & 210 \\
Prob/chi2 & $0.0079^{\mathrm{i}}$ & $0.0000^{\mathrm{i}}$ \\
\hline
\end{tabular}

Note: The initial values given in the table are IRR (Incidence Rate Ratio) values, and the values given in parentheses are z-statistic values.

i: Significant at level $1 \%$

v: Significant at level $5 \%$

The initial values given in the table show the Incidence Rate Ratio (IRR) values and the values given in parentheses show the $z$ statistic values. The IRR value gives the repeat rate of an event within a certain period. If the IRR value is greater than 1 , it is interpreted that the independent variable has a positive effect on the dependent variable (Knetter \& Prusa, 2003: 9-11). If the IRR value is less than 1, it is interpreted that the independent variable is having a negative effect. If the IRR value is 1 , there is no relationship between the dependent variable and the independent variables. For example, under the assumption that the IRR value calculated for the real exchange rate is 1.50 , a one-unit increase in the exchange rate, i.e., $100 \%$ appreciation of the exchange rate, results in a $50 \%$ increase in the dependent variable while all other variables are equal to their average. Under the assumption that the IRR calculated for the real exchange rate is 0.90 , a one-unit decrease in the exchange rate, i.e., $100 \%$ depreciation of the exchange rate, causes a decrease of $10 \%$ in the dependent variable while all other variables to be equal to their average.

According to the results, the model is statistically significant at $1 \%$ level (Prob/chi2 < 0.01). In high-income countries, fiscal protection instruments are only affected by the real exchange rate, while other variables do not have a statistical effect. The $z$ statistical value of the real exchange rate is significant at the $1 \%$ level. Thus, in high-income countries, an increase of $10 \%$ in real exchange rates would increase fiscal protection instruments by $0.1 \%$. This result is the opposite of the expected effect. In low and middle-income countries, while the growth rate, real exchange rate, and the unemployment rate affect the fiscal protection instruments, other variables do not affect them. The growth rate and real exchange rate are significant at $1 \%$, and the unemployment rate is significant at $5 \%$ level. Accordingly, in low and middle-income countries, a $1 \%$ decrease in the growth rate increases the fiscal protection instruments by $5 \%$, and this result is by the theory. A $10 \%$ increase in the real exchange rate increases the fiscal protection instruments by $1.1 \%$. A $1 \%$ decrease in the unemployment rate increases fiscal protection instruments by $3 \%$. The effect of the real exchange rate and the unemployment rate was reversed by the expected effect. 


\subsection{Results of Countries}

To be able to compare the countries, the mean and variance of the dependent variable in each country are calculated and shown in Table 9.

Table 9: Mean and Variances by Countries

\begin{tabular}{lcclcc}
\hline & Mean & Variance & & Mean & Variance \\
\hline Argentina & 11.318 & 35.18 & Indonesia & 3.5 & 9.405 \\
Australia & 6.773 & 25.898 & Japan & 0.5 & 1.024 \\
Brazil & 11.41 & 83.491 & Korea & 4.091 & 14.277 \\
Canada & 7.409 & 31.967 & Mexico & 5.955 & 25.188 \\
Chile & 1 & 1.143 & Russia & 1.818 & 7.775 \\
China & 9.045 & 70.426 & South Africa & 6.545 & 74.641 \\
EU & 16.091 & 118.277 & Turkey & 8.864 & 56.314 \\
India & 28.682 & 253.37 & USA & 23.273 & 164.398 \\
\hline
\end{tabular}

A total of 17 countries were taken into account in the analysis made by country groups, with seven countries with high-income and ten countries with low and middleincome. However, Guatemala is not included in the analysis for countries. The reason for this is the fact that Guatemala's use of fiscal protection instruments is not significant in the analysis because of the large number of zeros used.

When the mean and variance of the dependent variable is examined in each country, the variances are greater than the mean. This shows that the dependent variable has overdispersion. Therefore, the NBR method was used in the analysis. The results of NBR analysis are given in Table 10.

When the factors affecting the use of fiscal protection instruments in each country are examined, independent variables are statistically insignificant in Chile, Korea, and Mexico. In Argentina, Brazil, China, Indonesia, and Japan, macroeconomic factors affect the use of fiscal protection instruments as predicted in theory. It appears that macroeconomic factors have had the opposite effect that theoretically expected in Australia, Canada, the EU, India, Russia, South Africa, Turkey, and the USA. The main point is that macroeconomic factors are more effective in low and middle-income countries than high-income countries. 


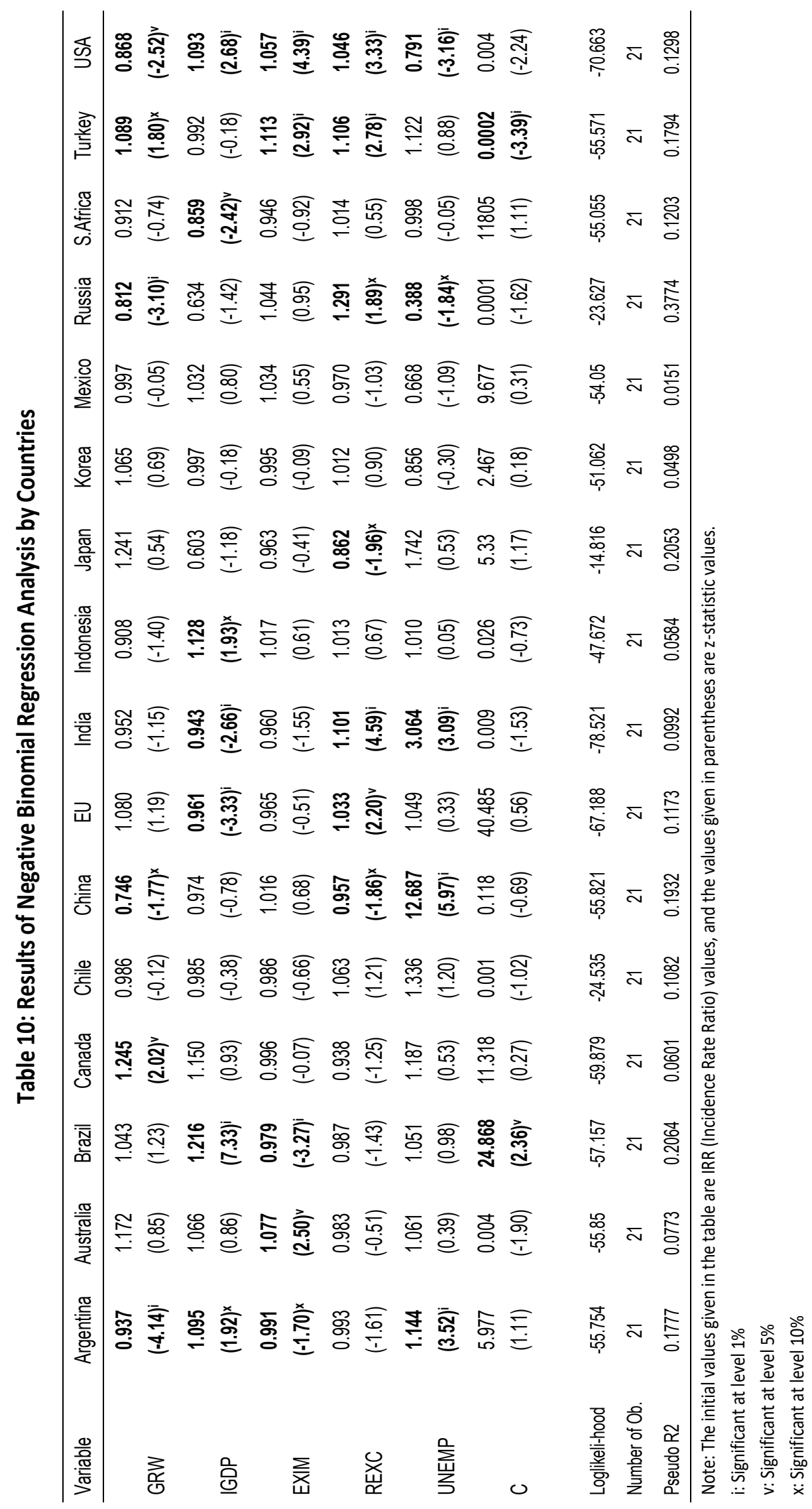


It is worth stressing that the factor of real effective exchange rate showed results corresponding to the theoretical predictions for high income countries. Real effective exchange rate can influence legally used application of the measures indicators and competition environment horizontally irrespective of a sector. Also, theoretically unexpected results were obtained mostly for large in size and diversified economies. It is natural to think that links between economic situations in particular sectors and macroeconomic situations are less strong and direct than in smaller and less diversified economies. Special factors could be important for China and Russia. These two countries may differ from other countries in the analysis. China and Russia were in the process of transformation reforms and thus they had to introduce step by step application of antidumping, countervailing and safeguard measures into their trade policy as use of such instruments had not been possible within the centralized economy. China and Russia accessed WTO in 2001 and 2012 respectively. Thus within the period analyzed China and Russia were in the process of development and legislation on the application of antidumping, countervailing and safeguarded measures and its adaptation to WTO rules. By the way, traditions and customs of applying technically complicated so called quasi-court trade policy instruments could also be important (for example the USA and Canada first used antidumping measures more than a century ago. These two countries apply the majority of the most technically difficult countervailing measures, and it is well known that Japan never applied countervailing measures). So it is worth taking into consideration such factors as traditions and experience in the application of the measures as developed legislation and qualified personnel are necessary. In addition, since 2015, Russia applies the measures on a collective basis as a member of the Eurasian Economic Union.

In summary, when the factors affecting the use of fiscal protection instruments of high-income countries are examined, it is observed that the effects of macroeconomic factors have an opposite effect, unlike expected effects. This shows that high-income countries do not use fiscal protection instruments fairly. In low and middle-income countries, the factors affecting the use of fiscal protection instruments are predominantly consistent with the theory. This shows that the low and middleincome countries act with completing their economic development and macroeconomic concerns. Although the stated objective of these instruments is to eliminate the injurious effect of unfair trade, their application in practice has nothing to do with maintaining a fair trading environment for high-income countries (Tabakis \& Zanardi, 2019: 1).

\section{Conclusion}

The study empirically contributes to the relationship between the growth rate, the share of imports in GDP, the ratio of exports to imports, the ratio of the real 
exchange rate and unemployment and trade protectionism regarding both country groups and each-countries. In the study, firstly, the high-income countries and low and middle-income countries were compared, after that, an analysis was conducted in 16 countries except for Guatemala. According to the results, while the real exchange rate only affects the use of fiscal protection instruments in high-income countries, the growth rate, real exchange rate, and unemployment rate affect the fiscal protection instruments in low and middle-income countries. When analyzed by each-countries, the factors affecting the use of fiscal protection instruments of high-income countries are observed to have an opposite effect predominantly unlike theory. This shows that high-income countries do not use fiscal protection instruments fairly. In low and middle-income countries, the factors affecting the use of fiscal protection instruments are predominantly consistent with the theory. This shows that the low and middleincome countries act with completing their economic development and macroeconomic concerns. The results show that fiscal protection instruments are affected by macroeconomic factors and countries, especially developed countries, use fiscal protection instruments beyond fair trade in case of unfair competition.

It is observed that fiscal protection instruments that are allowed to be used to prevent unfair competition within the scope of WTO do not serve this purpose both in the scope of the study and in the literature. These instruments, most commonly used by developed countries, are used for national interests without reasonable grounds. In order to prevent this situation and ensure fair trade in the world trade, the WTO should update the rules on the use of fiscal protection instruments and not follow policies that serve the interests of developed countries.

\section{References}

Aggarwal, A. (2004). "Macroeconomic determinants of antidumping: A comparative analysis of developed and developing countries", World Development, 32(6), 1043-1057.

Bagchi, S., Bhattacharyya, S. \& Narayanan, K. (2015). "Anti-dumping initiations in Indian manufacturing industries", South Asia Economic Journal, 16(2), 278-294.

Başkol, M. O. (2010). "Ithalatta Haksız Rekabetin Önlenmesinde Anti-Damping Soruşturmalarının Etkinliği", Ekonomi Bilimleri Dergisi, 2(1), 107-114.

Blonigen, B. A. (2005). "The effects of NAFTA on antidumping and countervailing duty activity", World Bank Economic Review, 19(3), 407-424.

Bown, C. P. (2008). "The WTO and antidumping in developing countries", Economics and Politics, 20(2), 255-288. 
Choi, C. H. \& Kim, J. W. (2014). "Determinants for Macroeconomic Factors of Antidumping: A Comparative Analysis of India and China", International Trade Journal, 28(3), 229-245.

Desai, P. \& Feinberg, R. M. (2019). “Are US antidumping cases being crowded out by other forms of protectionism?", Journal of International Trade Law and Policy, 19(1), 1-7.

Egger, P. \& Nelson, D. (2011). "How Bad Is Antidumping? Evidence From Panel Data”, Review of Economics and Statistics, 93(4), 1374-1390.

Engin, N. (1992). Uluslararası Ticarette Korumacı Eğilimler, İstanbul Ticaret Odası, İstanbul.

Feinberg, R. M. (1989). "Exchange Rates and "Unfair Trade"”, The Review of Economics and Statistics, 71(4), 704-707.

Feinberg, R. M. (2004). "U.S. Antidumping Enforcement and Macroeconomic Indicators: What Do Petitioners Expect, and Are They Correct?", Department of Economics, American University, Washington, DC., 20016-8029 (2007), 1-16. Available at: http://digitalcommons.uconn.edu/econ_wpapers (03.04.2018)

Feinberg, R. M. (2005). "U.S. Antidumping Enforcement and Macroeconomic Indıcators Revisited: Do Petitioners Learn?", Review of World Economics, 141(4), 612-622.

Finger, B. J. M., Hall, H. K. \& Nelson, D. R. (1982). "The Political Economy of Administered Protection", The American Economic Review, 72(3), 452-466.

Gbakou, P. M., Jallab, M. S. \& Sandretto, R. (2007). “Antidumping Procedures and Macroeconomic Factors: A Comparison between the United States and the European Union", Global Economy Journal, 6(3), 1-28.

Hallworth, T. \& Piracha, M. (2006). "Macroeconomic Fluctuations and Antidumping Filings: Evidence from a New Generation of Protectionist Countries", Journal of World Trade, 40(3), 407-423.

Hausman, J. (1978). "Speficitation Test in Econometrics", Econometrica, 46(6), 12511272.

Irwin, D. A. (2005). "The rise of US anti-dumping activity in historical perspective", World Economy, 28(5), 651-668.

Jallab, M. S., Gbakou, P. M. \& Sandretto, R. (2009). “Antidumping Procedures and Macroeconomic Factors: A Comparison Between The United States and The European Union", Global Economy Journey, 3, 1-28.

Knetter, M. M. \& Prusa, T. J. (2003). "Macroeconomic Factors and antidumping filings: Evidence from four countries", Journal of International Economics, 61(1), 1-17.

Leidy, M. P. (1997). "Macroeconomic Conditions And Pressures for Protection under Antidumping and Countervailing Duty Laws: Empirical Evidence from the United States", Staff Papers-International Monetary Fund, 44(1), 132-144. 
Li, R. (2018). "The Research on Factors Which Affect Anti-dumping Investigation: Based on Probit Model", International Journal of Business and Management, 13(3), 252-261.

Liu, Y. \& Deng, J. (2016). “Antidumping Under International Fragmentation: Evidence from China", Review of Development Economics, 20(1), 306-316.

Mah, J. S. \& Kim, Y. D. (2006). "Antidumping duties and macroeconomic variables: The case of Korea", Journal of Policy Modeling, 28(2), 157-162.

Moore, M. \& Zanardi, M. (2009). “Does antidumping use contribute to trade liberalization in developing countries?", Canadian Journal of Economics, 42(2), 469-495.

Moore, M. \& Zanardi, M. (2011). "Trade Liberalization and Antidumping: Is There a Substitution Effect?", Review of Development Economics, 15(4), 601-619.

Özer, H. \& Erkal, G. (2016). “Türkiye'nin Antidamping Uygulamalarının Ekonometrik Analizi", Atatürk Üniversitesi Iktisadi ve Idari Bilimler Dergisi, 30(2), 441-454.

Selen, U. (2020). "Why do countries use temporary trade barriers?", Applied Economic Letters, 27(6), 437-440.

Tabakis, C. \& Zanardi, M. (2019). "Preferential trade agreements and antidumping protection", Journal of International Economics, 121(2019), 1-15.

Wang, X. (2016). "What Factors Motivate Foreign Countries to Initiate an Antidumping Investigation against China?", The Regional Economics Applications Laboratory (REAL), REAL 16-T-3, 1-17.

Wooldridge, J. M. (2002). Introductory Econometrics: A Modern Approach Second Edition, South-Western College Publication, Cincinnati.

World Bank. (2018). Available at: https://datahelpdesk.worldbank.org/ knowledgebase/articles/906519-world-bank-country-and-lending-groups (12.12.2018).

World Trade Organization. (2019). Available at: https://www.wto.org (04.04.2018).

Zeng, K. (2011). "The political economy of developing country antidumping investigations against China", International Interactions, 37(2), 190-214.

Zhou, W. \& Cuyvers, L. (2009). "Determinants of EU antidumping actions against East Asian countries", Journal of International Trade Law and Policy, 8(3), 291-305. 